\title{
Duodenal-jejunal lining increases postprandial unconjugated bile acid responses and disrupts the bile acid-FXR-FGF19 axis in humans
}

Citation for published version (APA):

van Nierop, F. S., de Jonge, C., Kulik, W., Bouvy, N., Schaap, F. G., Damink, S. W. O., Rensen, S., Romijn, J. A., Greve, J. W. M., \& Soeters, M. R. (2019). Duodenal-jejunal lining increases postprandial unconjugated bile acid responses and disrupts the bile acid-FXR-FGF19 axis in humans. MetabolismClinical and Experimental, 93, 25-32. https://doi.org/10.1016/j.metabol.2018.12.009

Document status and date:

Published: 01/04/2019

DOI:

10.1016/j.metabol.2018.12.009

Document Version:

Publisher's PDF, also known as Version of record

\section{Document license:}

Taverne

Please check the document version of this publication:

- A submitted manuscript is the version of the article upon submission and before peer-review. There can be important differences between the submitted version and the official published version of record.

People interested in the research are advised to contact the author for the final version of the publication, or visit the DOI to the publisher's website.

- The final author version and the galley proof are versions of the publication after peer review.

- The final published version features the final layout of the paper including the volume, issue and page numbers.

Link to publication

\footnotetext{
General rights rights.

- You may freely distribute the URL identifying the publication in the public portal. please follow below link for the End User Agreement:

www.umlib.nl/taverne-license

Take down policy

If you believe that this document breaches copyright please contact us at:

repository@maastrichtuniversity.nl

providing details and we will investigate your claim.
}

Copyright and moral rights for the publications made accessible in the public portal are retained by the authors and/or other copyright owners and it is a condition of accessing publications that users recognise and abide by the legal requirements associated with these

- Users may download and print one copy of any publication from the public portal for the purpose of private study or research.

- You may not further distribute the material or use it for any profit-making activity or commercial gain

If the publication is distributed under the terms of Article $25 \mathrm{fa}$ of the Dutch Copyright Act, indicated by the "Taverne" license above, 


\title{
Duodenal-jejunal lining increases postprandial unconjugated bile acid responses and disrupts the bile acid-FXR-FGF19 axis in humans ${ }^{\text {is }}$
}

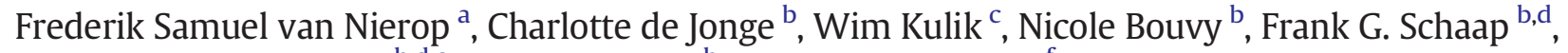 \\ Steven W. Olde Damink ${ }^{\text {b,d,e }}$, Sander Rensen ${ }^{\text {b }}$, Johannes A. Romijn ${ }^{\text {, }}$ \\ Jan Willem M. Greve ${ }^{\mathrm{b}, \mathrm{g}}$, Maarten R. Soeters ${ }^{\mathrm{a}, *}$
}

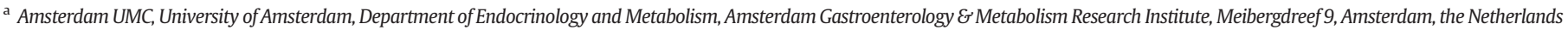

b Department of Surgery, NUTRIM School of Nutrition and Translational Research in Metabolism, Maastricht University, Universiteitssingel 50, 6229 ER, Maastricht, the Netherlands

c Amsterdam UMC, University of Amsterdam, Department of Clinical Chemistry, Laboratory Genetic Metabolic Diseases, Meibergdreef 9, Amsterdam, the Netherlands

d Department of General, Visceral and Transplantation Surgery, RWTH University Hospital Aachen, Aachen, Germany.

e Department of Surgery, Maastricht University Medical Center, Maastricht, the Netherlands

${ }^{\mathrm{f}}$ Amsterdam UMC, University of Amsterdam, Department of Medicine, Meibergdreef 9, Amsterdam, the Netherlands

${ }^{g}$ Department of General Surgery, Zuyderland Medical Center, Heerlen-Sittard, the Netherlands

\section{A R T I C L E I N F O}

\section{Article history:}

Received 30 September 2018

Accepted 29 December 2018

\section{Keywords:}

Bile acids

Duodenal-jejunal bypass liner

FGF-19

Type 2 diabetes

Obesity

\begin{abstract}
A B S T R A C T
Background and Aims: Placement of the duodenal-jejunal bypass liner (DJBL) leads to rapid weight loss and restoration of insulin sensitivity in a similar fashion to bariatric surgery. Increased systemic bile acid levels are candidate effectors for these effects through postprandial activation of their receptors TGR5 and FXR. We aimed to quantify postprandial bile acid, GLP-1 and FGF19 responses and assess their temporal relation to the weight loss and metabolic and hormonal changes seen after DJBL placement.

Methods: We performed mixed meal testing in 17 obese patients with type 2 diabetes mellitus (DM2) directly before, one week after and 6 months after DJBL placement.

Results: Both fasting and postprandial bile acid levels were unchanged at 1 week after implantation, and greatly increased 6 months after implantation. The increase consisted of unconjugated bile acid species. 3 hour-postprandial GLP-1 levels increased after 1 week and were sustained, whereas FGF19 levels and postprandial plasma courses were unaffected.

Conclusions: DJBL placement leads to profound increases in unconjugated bile acid levels after 6 months, similar to the effects of bariatric surgery. The temporal dissociation between the changes in bile acids, GLP-1 and FGF19 and other gut hormone responses warrant caution about the beneficial role of bile acids after DJBL placement. This observational uncontrolled study emphasizes the need for future controlled studies.
\end{abstract}

(C) 2019 Elsevier Inc. All rights reserved.

\footnotetext{
is Authors' contributions: FSvN performed laboratory analysis and statistical analysis and wrote and edited the manuscript. CMdJ designed the study, performed the clinical experiments, performed laboratory analysis and statistical analysis and reviewed and edited the manuscript. FS and WK performed laboratory analyses and reviewed the manuscript. JAR and SWOD reviewed the manuscript. SR and JWG designed the study, reviewed and edited the manuscript. FS performed laboratory analysis and statistical analysis and reviewed and edited the manuscript MRS performed data analyses, wrote, edited and reviewed the manuscript and takes full responsibility for the contents of the article.

* Corresponding author at: F5-161, Department of Endocrinology \& Metabolism, Internal Medicine, Amsterdam University Medical Centers, Meibergdreef 9, 1105AZ Amsterdam, the Netherlands.

E-mail addresses: m.r.soeters@amc.uva.nl,

URLs: http://metabolism.maartensoeters.nl, http://zorgophetbord.nl, http://amsterdamumc.nl (M.R. Soeters).
}

\section{Introduction}

Bile acids have gained attention as hormone-like factors in metabolism exerting effects via the transmembrane receptor Takeda G-coupled protein receptor 5 (TGR5) [1-4]. The feedback repression of hepatic bile acid synthesis is managed through the nuclear farnesoid X receptor (FXR) and involves ileal Fibroblast Growth Factor 19 (FGF19) [4,5]. Intestinal L-cell secretion of glucagon-like peptide 1 (GLP-1) is one of the best-described ways of in-vivo stimulation of TGR5 by bile acids [6].

Bile acids have been implicated in the deranged glucose metabolism of patients with obesity and type 2 diabetes mellitus (DM2) [7,8]. Obesity is characterized by decreased postprandial bile acid concentrations [9] and increased bile acid synthesis [10]. DM2 patients have increased postprandial plasma concentrations of the bile acids cholate (CA), deoxycholate (DCA) and chenodeoxycholic acid (CDCA) [11]. 
Bariatric surgery, and the Roux-en-Y gastric bypass procedure (RYGB) in particular, increases fasting and postprandial bile acid levels and results in $45 \%$ of patients not needing medication after 5 years $[12,13]$. The Duodenal-Jejunal Bypass Liner (DJBL, GI Dynamics, Lexington, MA) is a $60 \mathrm{~cm}$ long impermeable liner, which is delivered and retrieved endoscopically. Its placement results in weight loss and improvement of DM2 with lowering of the use of antidiabetic medication such as sulfonylurea derivatives, metformin and insulin [14-16].

Given the proposed role of bile acids in DM2 and RYGB, we examined the effects of DJBL placement on the postprandial bile acid response at different time points after the procedure.

\section{Material and Methods}

\subsection{Subjects}

Seventeen subjects with obesity and DM2 were included in the Maastricht University Medical Center, Maastricht, and the Atrium Medical Center Parkstad, Heerlen, the Netherlands between February and July 2010 as reported previously [17]. Inclusion criteria were: age between 18 and 65 years; body mass index (BMI) between 30 and $50 \mathrm{~kg} / \mathrm{m}^{2}$; duration of DM2 < 10 years; and $\mathrm{HbA} 1 \mathrm{c}$ between 7.5 and $10.0 \%$. Main exclusion criteria have been depicted earlier [17].
A

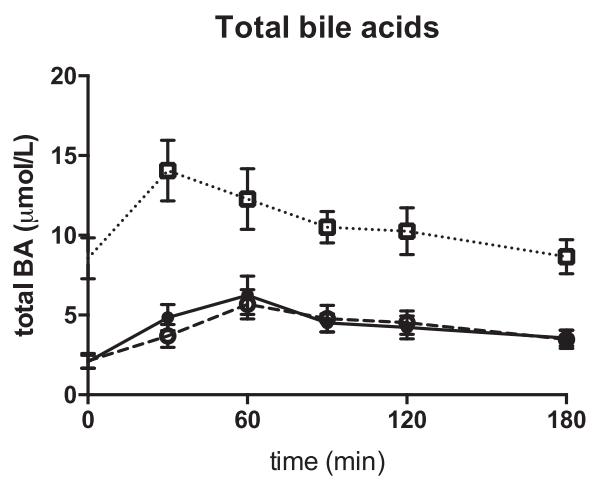

C

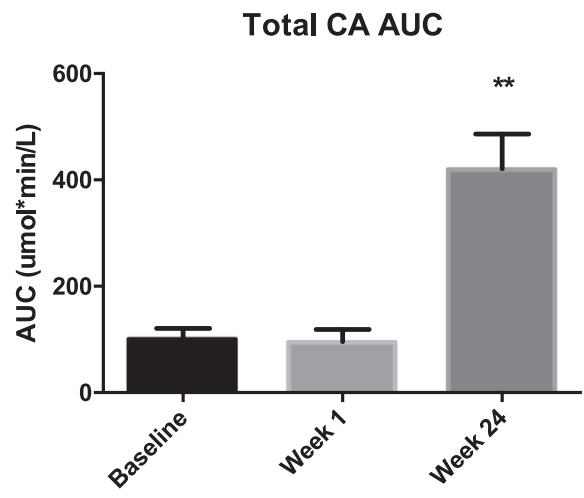

E

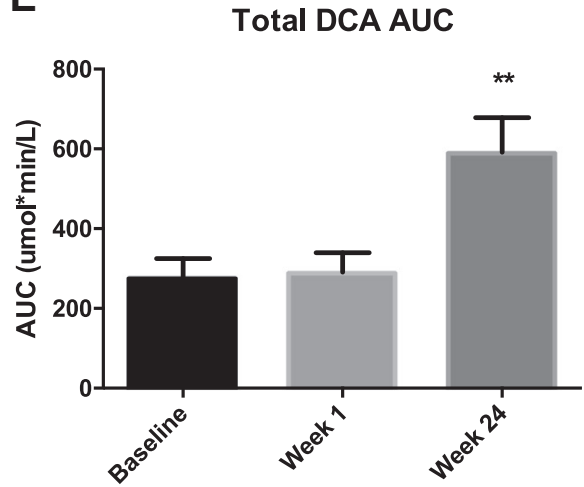

B

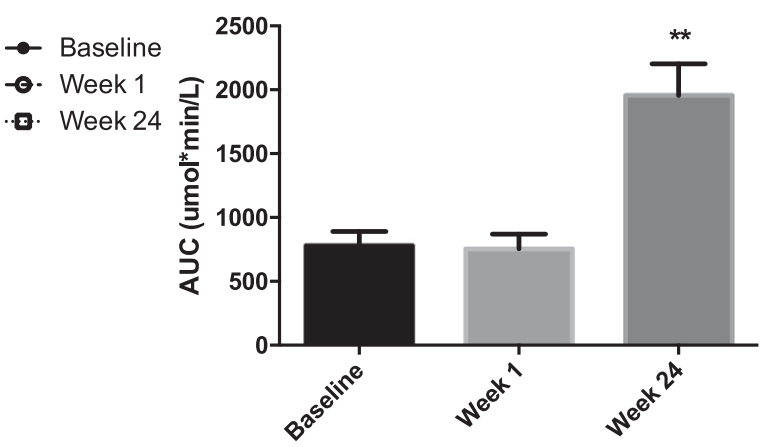

D

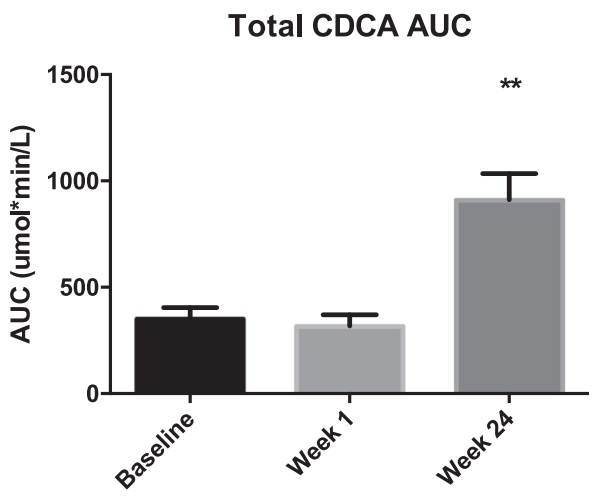

F

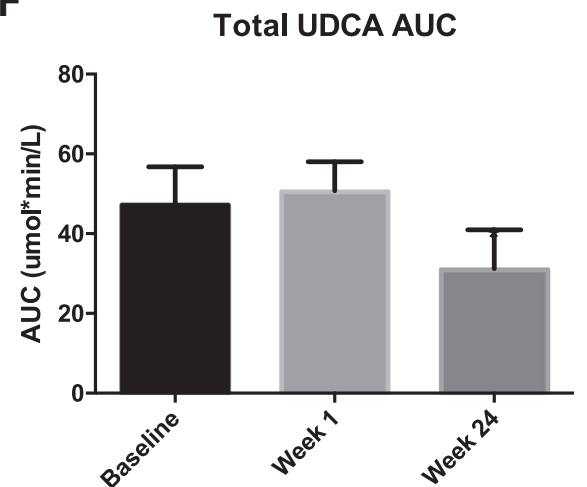

Fig. 1. Postprandial course of bile acids and AUC before DJBL placement and after 1 and 24 weeks of DJBL placement. ${ }^{* *}=p<0.05$. 


\subsection{Study Design}

The DJBL was delivered and retrieved endoscopically where after subjects were studied and followed up upon as described previously [17] Here, we report on three visits: 1) within one month prior to implantation (baseline), 2) one week after implantation (week 1), and 3) 24 weeks after implantation, just prior to removal (week 24). Standardized meal tolerance tests were performed. An intravenous cannula was placed for blood sampling. The first sample was drawn after an overnight fast; subsequently a standard liquid meal was consumed (Ensure Plus, Abbott Laboratories, IL; $333 \mathrm{~mL}, 500 \mathrm{kcal}, 20.8 \mathrm{~g}$ protein, $67.3 \mathrm{~g}$ carbohydrates, and $16.4 \mathrm{~g}$ fat), followed by collection of blood samples after 30, 60, 90, 120 and 180 min (BD Vacutainer EDTA tube/EDTA aprotinin tube, BD diagnostics, Erembodegem-Aalst, Belgium). Samples were immediately cooled, centrifuged, and stored at $-80^{\circ} \mathrm{C}$ until analysis.

\subsection{Laboratory Analysis}

Bile acid concentrations were determined using a UPLC-tandem MS method to quantify CA, CDCA, DCA and ursodeoxycholic acid (UDCA) in their conjugated and unconjugated forms [18]. FGF19 was measured using an in-house developed ELISA as published previously [19]. Total bile acids were calculated by adding up all the individual bile acids measurements.

\subsection{Ethics}

The study was approved by the Medical Ethics Committee of both centers and conducted according to the revised version of the Declaration of Helsinki. Written informed consent was obtained from every subject prior to study participation. Clinical Trial Registration Number: NCT00985114.

\subsection{Statistical Analysis}

Statistical analysis was performed using IBM SPSS Statistics 22 (IBM, Armonk, NY, USA). Data were visually and statistically assessed for normality and logarithmically transformed where appropriate. Areaunder-the-curve (AUC) of postprandial plasma levels was calculated using the trapezoidal method; subsequent correction for baseline values yielded the incremental-area-under-the-curve (iAUC). Peak time was defined as the first time point at which maximal concentration was reached. Comparisons between 3 test conditions were made using Friedman's test to determine significant differences. Individual comparisons between 2 test conditions were made with Wilcoxon matchedpairs signed rank testing. Correlations were assessed using Pearson's correlation for normally distributed populations or Spearman's Rho for other data. A $p$-value of $<0.05$ was considered statistically significant after Bonferroni corrections. Data presented are mean and standard deviation $(\mu \pm \sigma)$ for normally distributed variables or median and interquartile range ( $\mathrm{m}[\mathrm{IQR}])$ for other variables. Graphs were made using GraphPad Prism 6.0 (GraphPad Software Inc., La Jolla, CA, USA).

\section{Results}

\subsection{Lining of the Proximal Small Intestine by DJBL Reduces Body Weight}

The weight loss effects of the DJBL have been published previously [17]. At baseline, subjects ( 14 males, 3 females) were $51 \pm 2$ years old and weighed $116.0 \pm 5.8 \mathrm{~kg}$ with a BMI of $37.0 \pm 1.3 \mathrm{~kg} / \mathrm{m}^{2}$. One week after placement of the DJBL, body weight had decreased by $4.3 \pm 0.6 \mathrm{~kg}$, corresponding to an excess weight loss of $10.2 \pm 1.7 \%$ and a BMI reduction of $1.4 \pm 0.2 \mathrm{~kg} / \mathrm{m}^{2}(p<0.01)$. After 24 weeks, at the time of device removal, mean body weight had further decreased resulting in a total weight loss of $12.7 \pm 1.3 \mathrm{~kg}$, and a BMI reduction of $4.1 \pm 0.4 \mathrm{~kg} / \mathrm{m}^{2}(p<0.01)$. All

Table 1

Bilogram \& FGF19.

\begin{tabular}{|c|c|c|c|c|c|}
\hline Bile acid fraction & & Baseline & Week 1 & Week 24 & $p$ \\
\hline Total bile acids & Baseline & $1.1(1.5)$ & $1.6(1.4)$ & $7.8(3.9) * *^{*}$ & $<0.01$ \\
\hline \multirow{2}{*}{$(\mu \mathrm{mol} / \mathrm{L})$} & Peak & $4.8(9.0)$ & $5.9(8.4)$ & $13.1(6.5) *{ }^{*}$ & $<0.01$ \\
\hline & AUC & $679(642)$ & $602(722)$ & $1661(966) * *^{2}$ & $<0.01$ \\
\hline Total CA & Baseline & $0.1(0.1)$ & $0.2(0.3)$ & $1.6(1.3) * \dagger$ & $<\mathbf{0 . 0 1}$ \\
\hline \multirow[t]{2}{*}{$(\mu \mathrm{mol} / \mathrm{L})$} & Peak & $0.8(1.3)$ & $0.6(0.6)$ & $3.0(2.9) * *^{\prime}$ & $<0.01$ \\
\hline & AUC & $80(123)$ & $69(261)$ & $315(306) * \dagger$ & $<0.01$ \\
\hline Total CDCA & Baseline & $0.4(0.9)$ & $0.5(0.6)$ & $3.3(2.8) * \dagger$ & $<\mathbf{0 . 0 1}$ \\
\hline \multirow{2}{*}{$(\mu \mathrm{mol} / \mathrm{L})$} & Peak & $2.5(3.7)$ & $2.4(2.7)$ & $6.0(4.3) * *^{*}$ & $<0.01$ \\
\hline & AUC & $318(348)$ & $246(222)$ & $722(657) * \dagger$ & $<0.01$ \\
\hline Total DCA & Baseline & $0.5(0.4)$ & $0.6(0.6)$ & $2.8(2.3) * \dagger$ & $<\mathbf{0 . 0 1}$ \\
\hline \multirow[t]{2}{*}{$(\mu \mathrm{mol} / \mathrm{L})$} & Peak & $1.6(3.0)$ & $2.4(2.9)$ & $4.0(2.6) * \dagger$ & $<0.01$ \\
\hline & AUC & $222(278)$ & $246(327)$ & $519(326) * \dagger$ & $<0.01$ \\
\hline Total UDCA & Baseline & $0.0(0.1)$ & $0.2(0.2)$ & $0.0(0.2)$ & 0.13 \\
\hline \multirow[t]{2}{*}{$(\mu \mathrm{mol} / \mathrm{L})$} & Peak & $0.5(0.6)$ & $0.4(0.2)$ & $0.2(0.3) *$ & 0.03 \\
\hline & AUC & $45(39)$ & $53(33)$ & $14(41)$ & 0.08 \\
\hline \multirow{3}{*}{$\begin{array}{l}\text { Total taurine-conjugated BA } \\
(\mu \mathrm{mol} / \mathrm{L})\end{array}$} & Baseline & $0.1(0.8)$ & $0.1(0.2)$ & $0.0(0.1) * \dagger$ & 0.01 \\
\hline & Peak & $0.7(1.2)$ & $0.5(0.8)$ & $0.1(0.1) * \dagger$ & $<0.01$ \\
\hline & AUC & $50(126)$ & $54(56)$ & $6(24) * \dagger$ & $<0.01$ \\
\hline \multirow{3}{*}{$\begin{array}{l}\text { Total glycine-conjugated BA } \\
(\mu \mathrm{mol} / \mathrm{L})\end{array}$} & Baseline & $0.5(0.8)$ & $0.6(1.0)$ & $1.3(0.9)$ & 0.39 \\
\hline & Peak & $3.4(5.4)$ & $3.9(5.0)$ & $4.2(3.3)$ & 0.79 \\
\hline & AUC & $468(543)$ & 366 (438) & $422(306)$ & 0.19 \\
\hline \multirow{3}{*}{$\begin{array}{l}\text { Total unconjugated BA } \\
(\mu \mathrm{mol} / \mathrm{L})\end{array}$} & Baseline & $0.5(0.6)$ & $0.8(0.4)$ & $6.2(3.7) * \dagger$ & $<0.01$ \\
\hline & Peak & $1.3(1.6)$ & $1.5(0.6)$ & $8.1(6.2) * \dagger$ & $<0.01$ \\
\hline & AUC & $156(125)$ & $182(53)$ & 1118 (789)籼 & $<0.01$ \\
\hline \multirow{3}{*}{$\begin{array}{l}\text { Total } 12 \alpha-\mathrm{OH} \text { BA } \\
(\mu \mathrm{mol} / \mathrm{L})\end{array}$} & Baseline & $0.6(0.7)$ & $0.8(0.7)$ & $4.6(2.8) * \dagger$ & $<0.01$ \\
\hline & Peak & $2.5(5.0)$ & $3.2(3.5)$ & $6.4(4.0)^{*}+{ }^{*}$ & $<0.01$ \\
\hline & AUC & $335(401)$ & $324(404)$ & $834(467) * \dagger$ & $<0.01$ \\
\hline FGF19 & Baseline & $51.9(37.5)$ & $61.9(20.4)$ & $43.7(24.2)$ & 0.09 \\
\hline \multirow[t]{2}{*}{$(\mathrm{pg} / \mathrm{mL})$} & Peak & 70.7 (199.7) & $111.9(74)$ & $91.8(127.0)$ & 0.84 \\
\hline & AUC & $6303(7661)$ & $7986(2712)$ & $6694(3272)$ & 0.10 \\
\hline
\end{tabular}

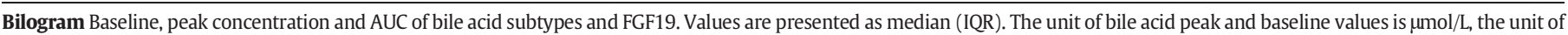

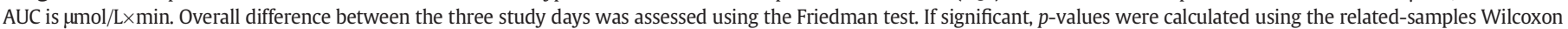
signed-rank test.

* Denotes significant difference compared to baseline.

$\dagger$ Denotes significant difference compared to week 1 . 
subjects reported lowered caloric intake during the study and $88 \%$ of the subjects (15/17) reported increased feelings of satiety.

3.2. Lining of the Proximal Small Intestine by DJBL Increases Fasting and Postprandial Unconjugated Bile Acid Levels

All subjects completed the study. AUC, fasting and peak levels of total bile acids and all bile acid subsets except UDCA were markedly increased 24 weeks after placement but not after 1 week (see Fig. 1 and Table 1). In fact, the increase of AUCs relied primarily on the increase in fasting plasma bile acids since incremental AUCs were unaffected by DJBL placement (data not shown). Peak times (time from start of the meal to the peak of the plasma bile acids) were unchanged for all bile acids and bile acid subfractions (data not shown).

\subsection{The Increase in Plasma Bile Acids by DJBL is Completely Caused by Un- conjugated Bile Acids}

To gain further insight in the composition of the bile acid pool after overnight fasting, we analysed the different bile acids species as well
A

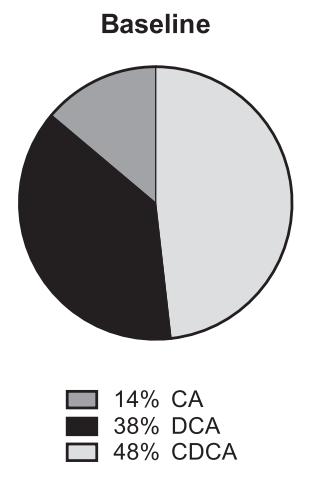

B
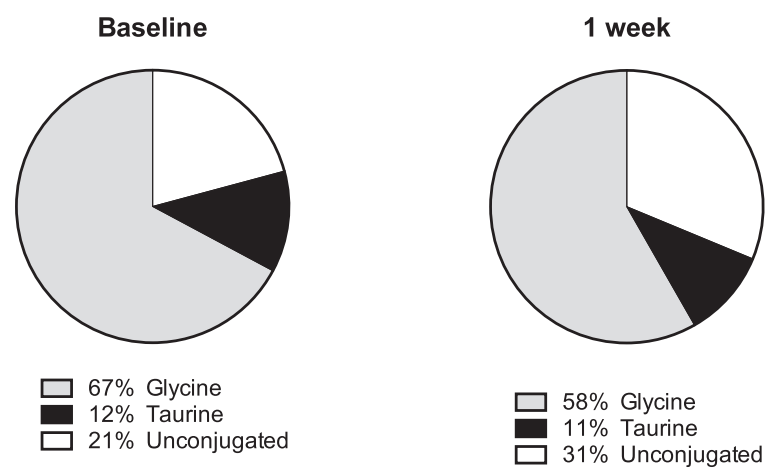

1 week

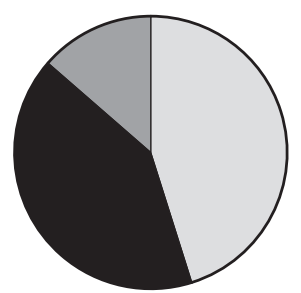

$14 \% \mathrm{CA}$

$41 \%$ DCA

$45 \%$ CDCA

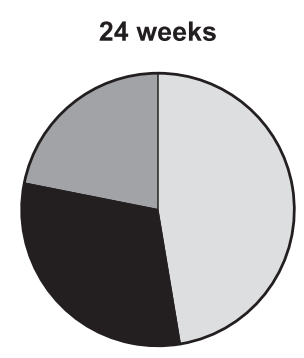

$22 \% \mathrm{CA}$

$31 \%$ DCA

$47 \% \mathrm{CDCA}$

C

\section{Ratio CA:DCA}

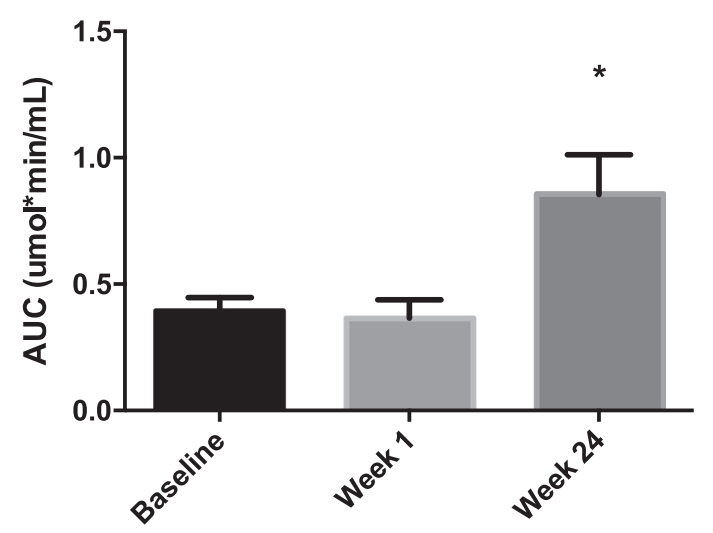

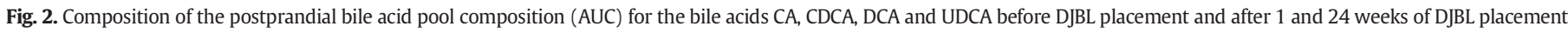

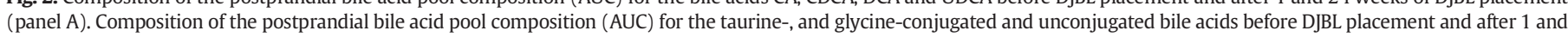
24 weeks of DJBL placement (panel B). ${ }^{* *}=p<0.05$. Ratio postprandial CA:DCA AUCs before DJBL placement and after 1 and 24 weeks of DJBL placement (panel C). ${ }^{*}=p<0.05$. 
A
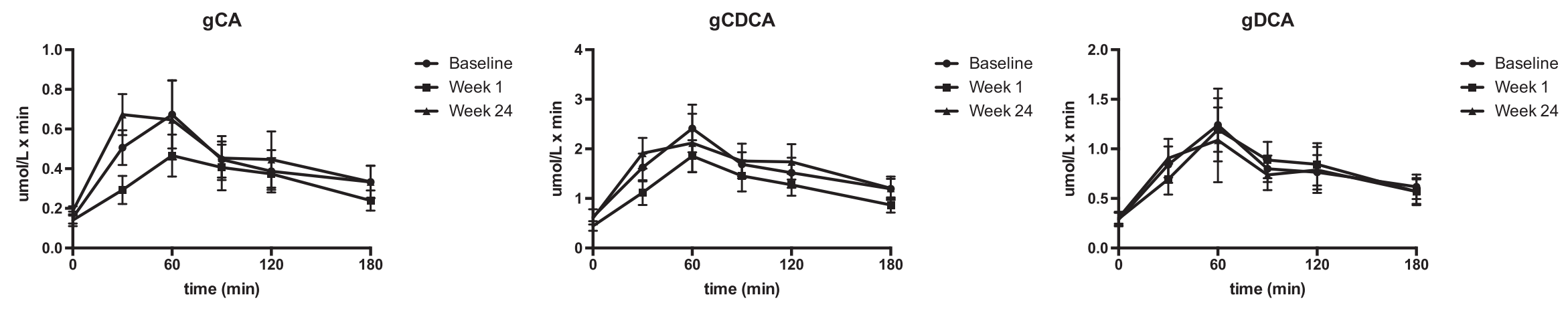

B

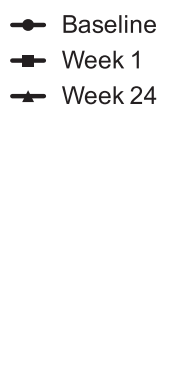

Baseline
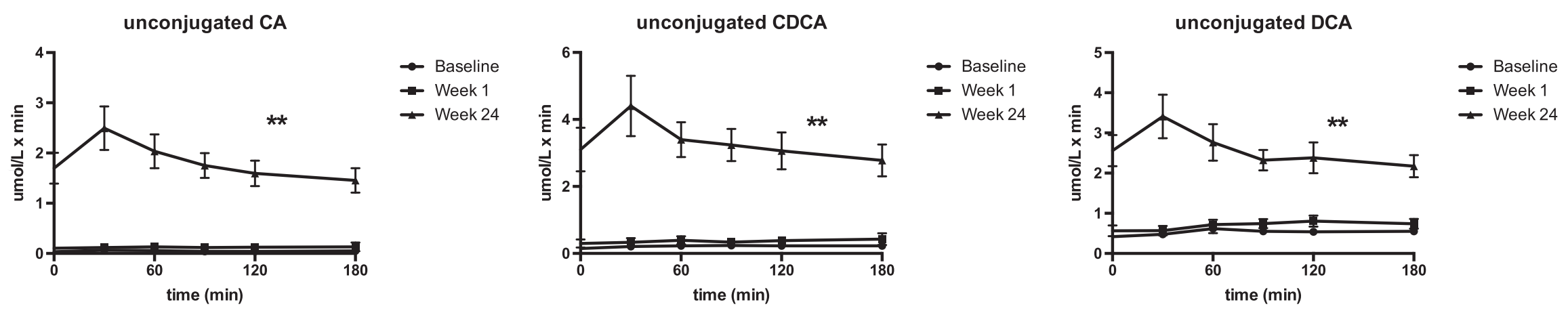

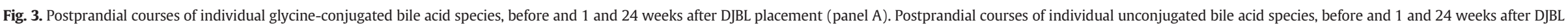
placement (panel A). ${ }^{* *}=p<0.05$. 
A

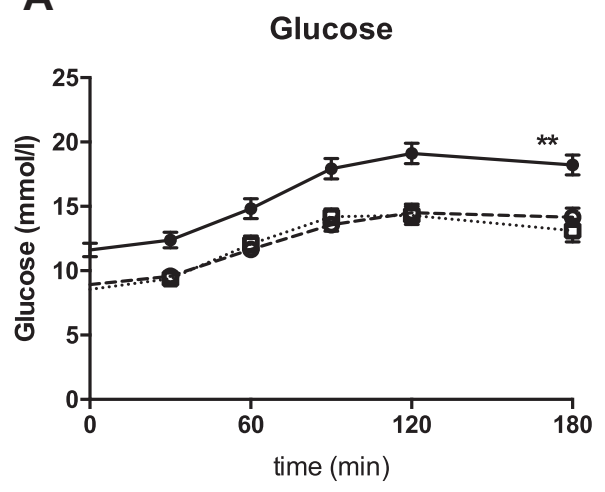

C

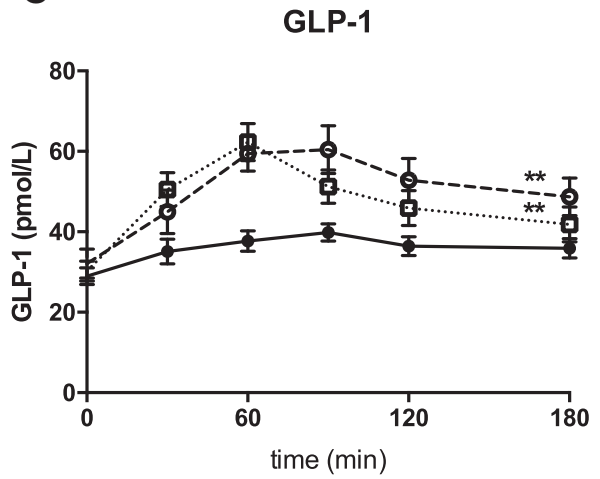

E

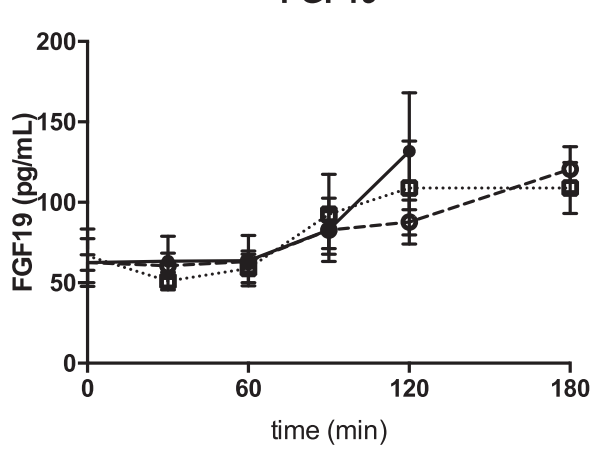

B

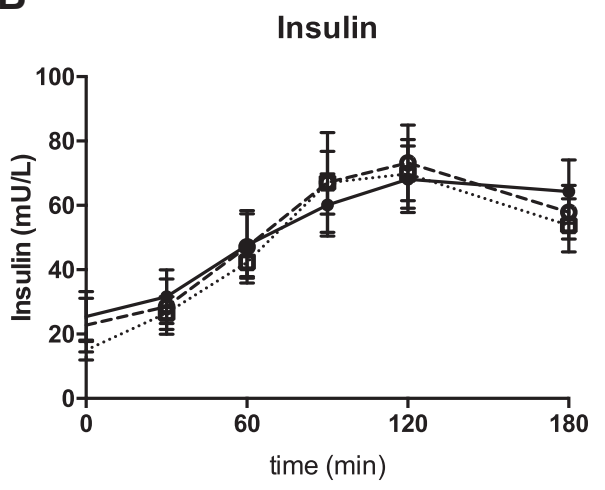

D

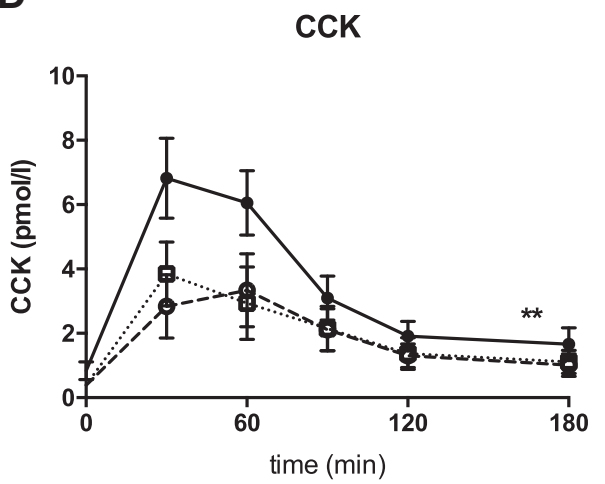

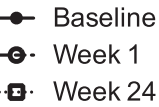

$\rightarrow$ Baseline

-๑. Week 1

๑. Week 24

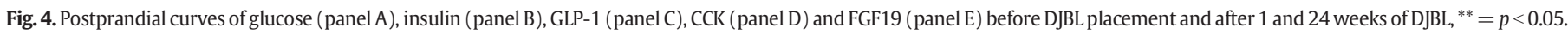
$T=180$ values are missing for FGF19 at baseline.

as the conjugation status (Fig. 2, panel A). In general, CDCA was the largest contributor to the pool during the entire study, followed by DCA and CA respectively. Remarkably, the increase in plasma bile acids was completely caused by unconjugated bile acids (Fig. 2, panel $B$ ), which reached significance after 24 weeks. Expressed as the fraction of total bile acids, unconjugated bile acid AUC rose from a median of $22 \%$ (IQR 13\%) at baseline to $26 \%$ (IQR 20\%, $p<$ $0.01^{* *}$ ) at week 1 and $76 \%$ (IQR $19 \%, p<0.01^{* *}$ ) at week 24 after placement. Total glycine conjugates were unaltered after 24 weeks in contrast to the taurine conjugates that showed a $\sim 90 \%$ reduction (Table 1). This pattern was also observed for the individual conjugated forms of CA, CDCA and DCA as shown in Fig. 3, emphasizing the fact that the increase in unconjugated plasma bile acids after DJBL was not due to one bile acid species. We found no changes in the ratio of $12 \alpha$-hydroxylated/non $12 \alpha$-hydroxylated bile acids (data not shown).
3.4. Postprandial Levels of Glucose, Insulin, GLP-1 Cholecystokinin (CCK) and FGF19

The effects of DJBL on glucose, insulin, GLP-1 and CCK in the studied subjects have been published previously $[16,17]$. In summary, duodenal lining lowered glucose and CCK within one week and led to increased postprandial AUC of GLP-1 at week 1 and week 24 after DJBL placement (Fig. 4). Insulin levels were not affected. The only bile acid species that consistently correlated with the AUC of GLP-1 on all study days, was fasting DCA: baseline: $r=0.50, p<$ $0.05^{*}$; week 1 after placement: $r=0.56, p<0.05^{*}$; week 24 after placement: $r=0.63, p<0.01^{* *}$. No other correlations were detected for bile acid species to AUC, fasting or peak levels of either glucose, CCK or GLP-1 (data not shown).

There were no significant differences in either fasting levels, postprandial plasma course, or postprandial levels of FGF19 at baseline, 
week 1 or week 24 after DJBL placement (see Table 1). However, at baseline, there were strong correlations between peak FGF19 and virtually all bile acids (peak total bile acids $r=0.79, p<0.001^{* * *}$; peak total CA, $r=0.78, p<0.001^{* * *}$; peak total CDCA, $r=0.79, p<0.001^{* * *}$ and peak total DCA, $r=0.63, p<0.007^{* * *}$ that were lost after DJBL placement. Likewise, postprandial AUC of FGF19 and AUC of total bile acids correlated $\left(r=0.84, p<0.001^{* * *}\right)$ at baseline but not after treatment. Individual AUCs of CA, CDCA or DCA did not correlate significantly with FGF19 AUC after Bonferroni correction. FGF19 samples at week 0 for timepoint $180 \mathrm{~min}$ were missing due to insufficient sample volume.

\section{Discussion}

Duodenal lining markedly increases fasting and postprandial levels of unconjugated bile acids 24 weeks after placement of the DJBL. The TGR5 target GLP-1 was higher after 1 and 24 weeks. Initial strong correlations of bile acids and FGF19 were lost at 1 week after placement. Bile acid levels were unchanged 1 week after placement, which supports the notion that the bile acid pool size may have increased gradually over time although metabolic improvements occurred immediately after placement [17]. This is in line with several studies performed in patients after RYGB surgery [12,20-23].

The DJBL-induced increase of bile acids was dependent on unconjugated bile acids, and more exaggerated compared to changes seen after RYGB surgery $[12,21,23-25]$. Dietary weight loss only marginally increases specific bile acids [26]. Hepatic conjugation of newly synthesized bile acids to occurs in the peroxisome, whereas re-conjugation of deconjugated bile acids occurs in the cytosol [27]. The reconjugation machinery is able to conjugate a potentially enlarged bile acid pool, as $>99 \%$ of serum bile acids in patients treated with large doses of unconjugated ursodeoxycholate is conjugated [28]. Changes in the gut microbiome are possibly responsible for our results. Bacterial deconjugation is complete in the cecum and gut biotransformation of bile acids (i.e. ratios of CA: DCA and CDCA:LCA) were altered after 24 weeks [29]. The DJBL may have led to a different interplay between bile acids, gut bacteria and the gut lumen with effects on entero-endocrine hormones that regulate motility, transit and bile salt reabsorption via the apical sodium-dependent bile acid transporter (ASBT). This could result in increased deconjugation and increased colonic uptake not buffered by liver clearance [30]. The initial increase in unconjugated bile acids after DJBL placement may go unnoticed until the amount of unconjugated bile acids reaches a tipping point, exceeding liver clearance.

It has been suggested that the increase in plasma bile acids after RYGB surgery may be due to increased bile acid recirculation and FXR dependent transcriptional upregulation [31,32]. The former could be achieved by adaptive growth and concomitant increases in ASBT. However, previous studies after RYGB were not unequivocal [12,21,23-25].

The increased GLP-1 seems attributable to increased TGR5 signalling in the gut, although insulin secretion remained unchanged. Moreover, GLP-1 levels increased at week 1 whereas bile acid levels increased later which may be explained by an early increase of bile acids in the gut that were not yet noticeable peripherally. Indeed, our findings are in partial agreement with a previous study that examined the effects of DJBL and also found increased GLP-1 levels [33]. However, this study did not investigate subfractions of bile acids. Interestingly, they were able to observe an increase in FGF19 that did not result in lower plasma bile acids. Most subjects with obesity or DM2 exhibit reduced serum FGF19 levels [34]. Here, FGF19 levels were unchanged throughout the entire study. The mismatch between plasma bile acid and FGF19 levels is difficult to explain FXR sensitivity to its ligand could be decreased, either as a cause of the increased circulating bile acid pool or as a consequence of it. A recent study in healthy subjects revealed that FXR agonist-induced repression of bile salt synthesis occurred without alterations in FGF19 level [35].

Our study has a few limitations. First, we were only able to perform a short mixed-meal test, which may have missed differences in postprandial signalling factors that occur later (such as FGF19 that peaks between 3 and $4 \mathrm{~h}$ ). Also, we were not able to document the exact moment where changes in bile acid homeostasis became apparent due to the timing of experiments at week 1 and 24. Additionally, this was an observational uncontrolled study emphasizing the need for future controlled studies. Finally, we did not quantify satiety and appetite with visual analogue scores.

In this study, duodenal lining led to beneficial improvements in glucose metabolism and weight in patients with DM2. Surprisingly, unconjugated bile acids showed a marked increase after 24 weeks whereas the increase in GLP-1 was evident after one week. In contrast, correlations of bile acids and FGF19 were abolished immediately. Our data suggest that future studies should be comparing effects of duodenal lining and other means of weight loss on bile acids, GLP-1 and FGF19 taking into account the time course of these changes.

\section{Disclosures}

No potential conflicts of interest or financial disclosures relevant to this article were reported.

\section{Grant Support}

This research was supported by a Dutch Diabetes Research Foundation Ruby grant (\#2011801423).

\section{References}

[1] Watanabe M, Houten SM, Mataki C, Christoffolete MA, Kim BW, Sato H, et al. Bile acids induce energy expenditure by promoting intracellular thyroid hormone activation. Nature 2006;439(7075):484-9.

[2] Sato H, Genet C, Strehle A, Thomas C, Lobstein A, Wagner A, et al. Antihyperglycemic activity of a TGR5 agonist isolated from Olea europaea. Biochem Biophys Res Commun 2007;362(4):793-8.

[3] Parks DJ, Blanchard SG, Bledsoe RK, Chandra G, Consler TG, Kliewer SA, et al. Bile acids: natural ligands for an orphan nuclear receptor. Science 1999;284(5418):1365-8.

[4] Watanabe M, Houten SM, Wang L, Moschetta A, Mangelsdorf DJ, Heyman RA, et al. Bile acids lower triglyceride levels via a pathway involving FXR, SHP, and SREBP1c. J Clin Invest 2004;113(10):1408-18.

[5] Kliewer SA, Mangelsdorf DJ. Bile acids as hormones: the FXR-FGF15/19 pathway. Dig Dis 2015;33(3):327-31

[6] Thomas C, Gioiello A, Noriega L, Strehle A, Oury J, Rizzo G, et al. TGR5-mediated bile acid sensing controls glucose homeostasis. Cell Metab 2009;10(3):167-77.

[7] Haeusler RA, Astiarraga B, Camastra S, Accili D, Ferrannini E. Human insulin resistance is associated with increased plasma levels of $12 \alpha$-hydroxylated bile acids. Diabetes 2013;62(12):4184-91.

[8] Brufau G, Stellaard F, Prado K, Bloks VW, Jonkers E, Boverhof R, et al. Improved glycemic control with colesevelam treatment in patients with type 2 diabetes is not directly associated with changes in bile acid metabolism. Hepatology 2010;52(4):1455-64

[9] Glicksman C, Pournaras DJ, Wright M, Roberts R, Mahon D, Welbourn R, et al. Postprandial plasma bile acid responses in normal weight and obese subjects. Ann Clin Biochem 2010;47(Pt 5):482-4.

[10] Haeusler RA, Camastra S, Nannipieri M, Astiarraga B, Castro-Perez J, Xie D, et al. Increased bile acid synthesis and impaired bile acid transport in human obesity. J Clin Endocrinol Metab 2016;101(5):1935-44.

[11] Sonne DP, van Nierop F Samuel, Kulik W, Soeters MR, Vilsbøll T, Knop FK, et al. Postprandial plasma concentrations of individual bile acids and FGF-19 in patients with type 2 diabetes. J Clin Endocrinol Metab 2016;101(8):jc20161607.

[12] Jørgensen NB, Dirksen C, Bojsen-Møller KN, Kristiansen VB, Wulff BS, Rainteau D, et al. Improvements in glucose metabolism early after gastric bypass surgery are not explained by increases in total bile acids and fibroblast growth factor 19 concentrations. J Clin Endocrinol Metab 2015;100(3):E396-406.

[13] Schauer PR, Kashyap SR, Wolski K, Brethauer SA, Kirwan JP, Pothier CE, et al. Bariatric surgery versus intensive medical therapy in obese patients with diabetes. N Engl J Med 2012;366(17):1567-76.

[14] Escalona A, Pimentel F, Sharp A, Becerra P, Slako M, Turiel D, et al. Weight loss and metabolic improvement in morbidly obese subjects implanted for 1 year with an endoscopic duodenal-jejunal bypass liner. Ann Surg 2012;255(6):1080-5.

[15] Schouten R, Rijs CS, Bouvy ND, Hameeteman W, Koek GH, Janssen IMC, et al. A multicenter, randomized efficacy study of the EndoBarrier Gastrointestinal Liner for presurgical weight loss prior to bariatric surgery. Ann Surg 2010;251(2):236-43.

[16] de Jonge C, Rensen SS, Verdam FJ, Vincent RP, Bloom SR, Buurman WA, et al. Impact of duodenal-jejunal exclusion on satiety hormones. Obes Surg 2016;26(3):672-8.

[17] de Jonge C, Rensen SS, Verdam FJ, Vincent RP, Bloom SR, Buurman WA, et al. Endoscopic duodenal-jejunal bypass liner rapidly improves type 2 diabetes. Obes Surg 2013;23(9):1354-60.

[18] Bootsma AH, Overmars H, van Rooij A, van Lint AE, Wanders RJ, van Gennip AH, et al. Rapid analysis of conjugated bile acids in plasma using electrospray tandem mass 
spectrometry: application for selective screening of peroxisomal disorders. J Inherit Metab Dis 1999;22(3):307-10

[19] Lips MA, De Groot GH, Berends FJ, Wiezer R, Van Wagensveld BA, Swank DJ, et al. Calorie restriction and Roux-en-Y gastric bypass have opposing effects on circulating FGF21 in morbidly obese subjects. Clin Endocrinol (Oxf) 2014;81(6):862-70.

[20] Patti M-E, Houten SM, Bianco AC, Bernier R, Larsen PR, Holst JJ, et al. Serum bile acids are higher in humans with prior gastric bypass: potential contribution to improved glucose and lipid metabolism. Obesity 2009;17(9):1671-7.

[21] Kohli R, Bradley D, Setchell KD, Eagon JC, Abumrad N, Klein S. Weight loss induced by Roux-en-Y gastric bypass but not laparoscopic adjustable gastric banding increases circulating bile acids. J Clin Endocrinol Metab 2013;98(April):708-12.

[22] LaRusso NF, Hoffman NE, Korman MG, Hofmann AF, Cowen AE. Determinants of fasting and postprandial serum bile acid levels in healthy man. Am J Dig Dis 1978; 23(5):385-91.

[23] Dutia R, Embrey M, O'Brien CS, Haeusler RA, Agénor KK, Homel P, et al. Temporal changes in bile acid levels and $12 \alpha$-hydroxylation after Roux-en-Y gastric bypass surgery in type 2 diabetes. Int J Obes (Lond) 2015;39(April):806-13.

[24] Sachdev S, Wang Q, Billington C, Connett J, Ahmed L, Inabnet W, et al. FGF 19 and bile acids increase following Roux-en-Y gastric bypass but not after medical management in patients with type 2 diabetes. Obes Surg 2016;26(5):957-65.

[25] De Giorgi S, Campos V, Egli L, Toepel U, Carrel G, Cariou B, et al. Long-term effects of Roux-en-Y gastric bypass on postprandial plasma lipid and bile acids kinetics in female non diabetic subjects: a cross-sectional pilot study. Clin Nutr 2015;34(5):911-7.

[26] van Nierop FS, Kulik W, Endert E, Schaap FG, Olde Damink SW, Romijn JA, et al. Effects of acute dietary weight loss on postprandial plasma bile acid responses in obese insulin resistant subjects. Clin Nutr 2016;13:1-6.

[27] Pellicoro A, van den Heuvel FAJ, Geuken M, Moshage H, Jansen PLM, Faber KN. Human and rat bile acid-CoA:amino acid N-acyltransferase are liver-specific peroxisomal enzymes: implications for intracellular bile salt transport. Hepatology 2007;45(2):340-8

[28] Gurantz D, Schteingart CD, Hagey LR, Steinbach JH, Grotmol T, Hofmann AF. Hypercholeresis induced by unconjugated bile acid infusion correlates with recovery in bile of unconjugated bile acids. Hepatology 1991;13(3):540-50.

[29] Hamilton JP, Xie G, Raufman J-P, Hogan S, Griffin TL, Packard CA, et al. Human ceca bile acids: concentration and spectrum. Am J Physiol Gastrointest Liver Physio 2007;293(1):G256-63.

[30] Eggink HM, van Nierop FS, Schooneman MG, Boelen A, Kalsbeek A, Koehorst M, et al. Transhepatic bile acid kinetics in pigs and humans. Clin Nutr 2017;37(4):1-9.

[31] Docherty NG, Le Roux CW. Physiological adaptations following Roux-en-Y gastric bypass and the identification of targets for bariatric mimetic pharmacotherapy. Curr Opin Pharmacol 2015;25(18):23-9.

[32] Pournaras DJ, Glicksman C, Vincent RP, Kuganolipava S, Alaghband-Zadeh J, Mahon $\mathrm{D}$, et al. The role of bile after Roux-en-Y gastric bypass in promoting weight loss and improving glycaemic control. Endocrinology 2012;153(August):1-7.

[33] Kaválková P, Mráz M, Trachta P, Kloučková J, Cinkajzlová A, Lacinová Z, et al. Endocrine effects of duodenal-jejunal exclusion in obese patients with type 2 diabetes mellitus. J Endocrinol 2016;231(1):11-22.

[34] Zhang F, Yu L, Lin X, Cheng P, He L, Li X, et al. Minireview: roles of fibroblast growth factors 19 and 21 in metabolic regulation and chronic diseases. Mol Endocrinol 2015;29(10):1400-13.

[35] Al-khaifi A, Rudling M, Angelin B. An FXR agonist reduces bile acid synthesis independently of increases in FGF19 in healthy volunteers. Gastroenterology 2018 Oct; 155(4):1012-6. 